\title{
IMPROVING STUDENTS' WRITING SKILLS IN RECOUNT TEXT USING TEACHING MEDIA PICTURES AND LEARNING INTERESTS
}

\author{
E. Laela Komala Susilawati ${ }^{1}$ \\ English Education Program Postgraduate Faculty \\ Universitas Indraprasta PGRI,Jakarta \\ e-mail: komala.laela@gmail.com ${ }^{1}$
}

\begin{abstract}
This experimental study aims to determine the effects of teaching media and learning interest on students' writing skills in recount text. The sample of the research is 80 respondents. The technique of collecting data of each variable was acquired from the test. The data were analyzed using a two-way analysis of variance (ANOVA 2x2). The research shows that: 1) there is a significant effect of teaching media towards students writing skills in recount text at State Senior High School in Pandeglang Regency. It is proved by the value Sig $0,000<0,05$ and $F_{o}=87,444 ; 2$ ) there is a significant effect of learning interest towards students writing skill in recount text at State Senior High School in Pandeglang Regency. It is proved by the value Sig $0,000<0,05$ and $\mathrm{F}_{\mathrm{o}}=$ 46,$751 ; 3$ ) there are no significant interactive effects of teaching media and learning interest towards students' writing skills in recount text at state senior high school in Pandeglang Regency. It is proved by the value Sig 0,05 or $0,380>0,05$ and $F_{o}=0,778$.
\end{abstract}

Keywords: teaching media, learning interest, writing skills, recount text.

\section{Introduction}

English is essential; it is used in almost every part of the world because English is an international language. Many countries offer English as their lesson in schools to be learned by their students, whether in elementary schools, secondary schools, or even kindergarten. In Indonesia, English is a compulsory subject in Elementary, Junior, and Senior high schools. It also becomes one of the subjects tested in the National Examination (Ujian Nasional). Therefore, all students need to learn English to achieve academic purposes. The purposes of teaching English in school are to develop students' communicative competencies in English because, in many fields of professional jobs, English competencies are needed.

There are four skills that students should be mastered in learning English. Writing is a part of four language skills necessary to be mastered by the students. Weigle,2002 stated that the ability to write well is becoming increasingly important in our global community. Moreover, a workplace needs people who master English well, especially on the transactional letter. In addition, based on the 2013 Indonesian Curriculum, the students at Senior High School should identify the texts' social function, generic structure, and linguistic features. They are expected to produce short-spoken and written text (Kementrian Pendidikan dan Kebudayaan, 2016). It means that writing has an essential role in English teaching and learning.

Writing is transferring a writer's information and knowledge from reading or others, which was changed in the word. Writing also expands their knowledge, bases and develops new knowledge by processing new information to write on a topic. We know that writing is one of English skill. It is also so crucial for English learners. Writing is a skill to share ideas what they think. For students, writing is a primary medium through which to demonstrate what they understand. Students will explore their idea; their understanding through writing, and writing is proof of their understanding. Besides that, writing is knowledge transforming. Knowledge transforming is considerably more cognitive complex than knowledge telling because writers do not merely retrieve information already available to them in memory but derive it from reading and integrate it with that already available to become obtained knowledge. 
A good choice of words characterizes good writing, but many students cannot use appropriate words in their writing. Students are expected to write sentences with no grammar errors, but grammatical errors are the common errors in students' writing. Good writing is also characterized by good cohesion, coherence, and mechanics, but many students fail in these micro-skills.

Most senior high school students thought that writing is the most difficult skill to be masteredthe difficulty in generating and organizing the ideas and vocabulary, grammar, and mechanics' use. Consequently, the students feel bored and have less interest in writing. This implies that the teachers should be creative in the teaching of writing. English teachers need to find the solution to solve the students' problems in writing. Teachers can use several alternatives to improve students' achievement in writing. One of them is the use of media, such as pictures.

The teacher should be selective in choosing teaching media/aids. Therefore, using pictures is one of the effective media for students in making written works. The teacher hopes to use the picture as the aids will help students develop their writing ability. In addition, to make the students interested in the writing teaching and learning process, the teacher may use learning media. Learning media contributes to students' interest in the learning process of writing skills. They can stimulate students' ideas to develop their writing.

One alternative way to support the student in eliciting ideas to write is using pictures. As visual media, pictures allow the complex idea to be easily conveyed (Kess, 2010). The idea is supported by some empirical research that reports that visual media such as pictures or photographs do not just convey meaning but represent the external narrative of reality and figure out the way persons think and act. The use of pictures as visual media in the teaching and learning process more effective so that the student's writing ability can be improved.

The text types learned by Senior High School Students based on the 2013 curriculum are descriptive, narrative, explanation, exposition, discussion, and recount text. Furthermore, the statement of competence in the 2013 curriculum also uses communicative purpose, text structure, and linguistic features. In this research, the writer would discuss recount texts. The reason for choosing recount text as the object of this research is that usually, the students at senior high school faced some difficulties in constructing recount text because of lack of vocabulary, conjunction, tenses, structure, and mainly used phrases in writing recount text, so the students feel under esteemed to do it, and the teacher should have any effort to solve this problem.

Writing activity requires the students to write after getting the model. As they regard that writing is difficult, they can think that writing is not interesting. The students have to be stimulated through interesting activities to make them interested in the class. Learning media can contribute to motivation in students' English learning. By using media, students can develop their idea and vocabulary. In addition, the use of media in teaching writing can make the students interested in the lesson. Based on the background above, the writer wants to research with the title;" Improving Students' Writing Skill in Recount Text Using Teaching Media Pictures and Learning Interest."

\section{Method}

This research used quantitative research. Aliaga \& Gunderson (2002:81) stated that Quantitative research is 'Explaining phenomena by collecting numerical data that are analyzed using mathematically based methods (statistics). Muijs (2004:2) stated that quantitative research is essentially about collecting numerical data to explain a particular phenomenon. In doing this research, the writer uses the experiment method to give the different treatments to two student's learning groups. One group is treated as experiment classes, which is given the treatment of teaching media using pictures as teaching media. In comparison, other groups are control classes, which are not given the treatment of teaching media. For each group, then it will be given pretest and posttest of writing recount text.

This research examines the effect of two independent variables that are teaching media $\left(X_{1}\right)$, learning interest $\left(X_{2}\right)$ and one dependent variable, namely students' writing skill in recount text $(Y)$. The design in this study is a factorial design $2 \times 2$ as follows: 
Table 1. Factorial Design 2x2

\begin{tabular}{|c|c|c|}
\hline \multirow{2}{*}{$\begin{array}{c}\text { Learning } \\
\text { Interest }\end{array}$} & \multicolumn{2}{|c|}{ Teaching Media } \\
\cline { 2 - 3 } & $\begin{array}{c}\text { (Pictures) } \\
\text { (A1) }\end{array}$ & $\begin{array}{c}\text { Conventional } \\
\text { (A2) }\end{array}$ \\
\hline$B_{1}$ (High) & $A_{1} B_{1}$ & $A_{2} B_{1}$ \\
\hline$B_{2}$ (Low) & $A_{1} B_{2}$ & $A_{2} B_{2}$ \\
\hline Total & $A$ & $B$ \\
\hline
\end{tabular}

Information of Table 1 will be as follows:

$A_{1}$ : The students who get the treatment by Teaching media pictures.

$A_{2}$ : The students who get the treatment by conventional teaching.

$B_{1}$ : The students who have high interest.

$B_{2}$ : The students who have low interest.

$A_{1} B_{1}$ : The students who get treatment by teaching media pictures and have high interest.

$A_{1} B_{2}$ : The students who get treatment by teaching media pictures and have low interest.

$A_{2} B_{1}$ : the students who get treatment by conventional approach and have high interest.

$A_{2} B_{2}$ : the students who get treatment by conventional approach and have low interest.

The Effect of Teaching Media $\left(X_{1}\right)$ and learning Interest $\left(X_{2}\right)$ towards Students Writing Skill in Recount text (Y), in which:

- Independent Variable (A): Teaching Media

- Independent Variable (B): Learning Interest

- Dependent Variable (Y): Writing Skill in Recount Text

\section{Results and Discussion}

A. Description of Research Result data

The research is an experimental study of two factors: teaching media (A) and learning interest (B). Each factor consists of a sub-factor called level. There are two levels for teaching media (A), namely teaching media by using pictures (A1) and conventional approach (A2). Another factor is learning interest (B) with two levels there are: high (B1) and low (B2).

\section{The result of students writing skills taught by teaching media (Al).}

From 40 students who are chosen as the sample in this research, they are treated using teaching media could get the lowest score is 65 , and the highest score is 96 , with a mean of 72.53 . A median also supports it is 70,5 , the mode is 65 , and the standard deviation is 9,959 . Here is the complete data, which is showed in Table 2. The summary of the data is displayed in Graph 1.

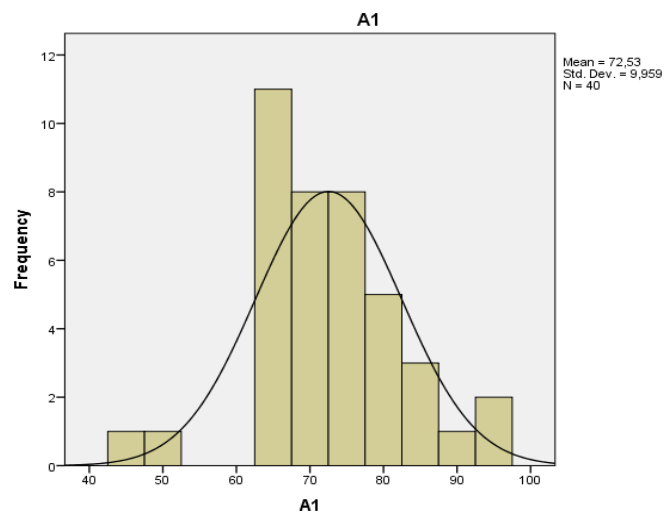

Graph 1 Histogram and Polygon graph of students' writing skills taught by teaching media pictures 
INFERENCE: Journal of English Language Teaching

Vol. 4, No. 1, April - July 2021

p-ISSN: 2615-8671

e-ISSN: 2615-868X

From the histogram and polygon frequency graph above, we can see that spread level data of students' writing skill in recount text taught by teaching media pictures in this research is relatively normal.

2. The results of students' writing skills taught by conventional approach (A2).

From 40 students who are chosen as the sample in this research, they are treated using conventional approach could get the lowest score is 35 , and the highest score is 80 , with a mean of 53,03 . The median also supports it is 50,00 , the mode is 50 , and the standard deviation is 10,386 . Here is the complete data, which is showed in Graph 2.

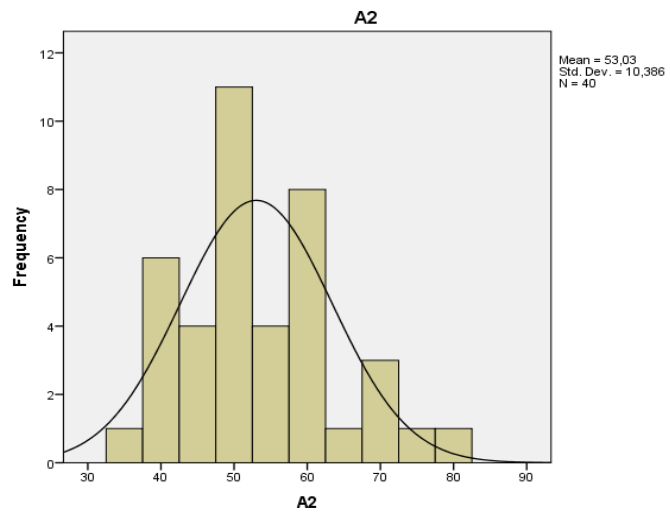

Graph 2 Histogram and polygon graph of Students' Writing Skill Taught by Conventional Approach (A2)

From the graph of histogram and polygon frequency above, we can see that spread level data of students' writing skill in recount text taught by conventional approach in this research is relatively normal.

\section{The result of students writing skill who have high interest (B1).}

From 40 students chosen as the sample in this research, they are treated using teaching media and have high interest could get the lowest score is 65 . The highest score is 96 , with a mean of 69,37 and a median also supports it is 71,0 , the mode is 60 , and the standard deviation is 12,496 . Here is the complete data, which is showed in Graph 3.

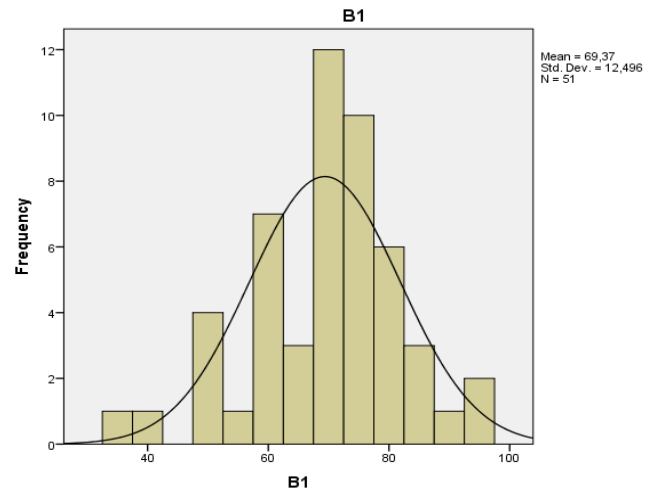

Graph 3 Histogram and polygon graph of students writing skill who have high interest (B1)

From the graph of histogram and polygon frequency above, we can see that spread level data of students' writing skill in recount text taught by teaching media pictures and have high interest in this research is relatively normal.

4. The result of students writing skills who have low interest (B2).

From 40 students chosen as the sample in this research, they are treated using teaching media and have low interest to get the lowest score of 38 . The highest score is 69 , with a mean of 53,97, and a 
median also supports it is 51 , the mode is 65 , and the standard deviation is 10,038 . Here is the complete data, which is showed in Graph 4.

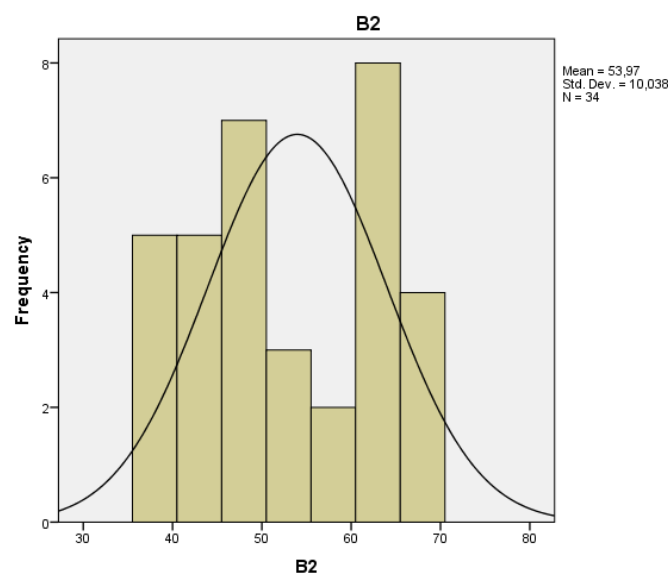

Graph 4 Histogram and polygon graph of students writing skill who have low interest (B2)

From the graph of histogram and polygon frequency above, we can see that spread level data of students' writing skill in recount text taught by teaching media pictures and have low interest in this research is relatively normal. The summary of descriptive data that can be used for the analysis process can be seen in Table 2 .

Table 2 Data Description of Research

\begin{tabular}{|c|c|c|c|c|}
\hline \multicolumn{5}{|c|}{ Descriptive Statistics } \\
\hline \multicolumn{5}{|c|}{ Dependent Variable: Writing skill } \\
\hline Teaching Media & Student Interest & Mean & Std. Deviation & N \\
\hline \multirow{3}{*}{ Teaching Media } & High & 77,54 & 7,458 & 26 \\
& Low & 63,21 & 6,852 & 14 \\
& Total & 72,52 & 9,959 & 40 \\
\hline \multirow{3}{*}{ Conventional } & High & 58,55 & 11,014 & 20 \\
& Low & 47,5 & 5,987 & 20 \\
& Total & 53,03 & 10,386 & 40 \\
\hline \multirow{3}{*}{ Total } & High & 69,28 & 13,141 & 46 \\
& Low & 53,97 & 10,038 & 34 \\
& Total & 62,78 & 14,088 & 80 \\
\hline
\end{tabular}

Based on the data above, the students' writing skill result taught by teaching media pictures and have high interest consist of 26 students could get the mean of score 77,54 and standard deviation 7,458 or the students' writing skill result taught by teaching media and have low interest consist of 14 students could get the mean of score 63,21 and standard deviation 6,852. Based on the data above, the students' writing skill result taught by conventional approach and have high interest consist of 20 students could get the mean of score 58,55 and standard deviation 11,014 for the students' writing skill result taught using conventional approach and have low interest consist of 20 students could get the mean of score 47,5 and standard deviation 5,987.

\section{B. Analysis Required Test}

Normality test toward to research data, the calculation is calculated using SPSS 20.0. The first step of the analysis required test is the normality test; this test is done to know whether the hypothesis's data distribution is normal.

$\mathrm{H}_{0}$ : the data is from the population is normal.

$\mathrm{H}_{1}$ : the data is not from the population that is normal. 
INFERENCE: Journal of English Language Teaching

Vol. 4, No. 1, April - July 2021

p-ISSN: 2615-8671

e-ISSN: 2615-868X

Criteria of a hypothesis test are as follows:

Accepted $\mathrm{H}_{0}$ (refused $\mathrm{H}_{1}$ ) if the significance score $>0.05$ or refused $\mathrm{H}_{0}$

(Accepted $\mathrm{H}_{1}$ ) if the significance score $<0.05$.

Here is the summary of data analysis of normality test for each group of students' writing skill in recount text result.

Tabel 3 The Computation of Normality Test

One-Sample Kolmogorov-Smirnov Test

\begin{tabular}{|c|c|}
\hline & Writing skill \\
\hline \begin{tabular}{cc} 
& $\mathrm{N}$ \\
Normal & Mean \\
Parameters & \\
Most Extreme & Std.Deviation \\
Differences & Absolute \\
\multicolumn{2}{c}{ Kolmogorov-Smirnov Z } \\
Asymp. Sig. (2-tailed)
\end{tabular} & $\begin{array}{c}80 \\
62,78 \\
14,088 \\
, 105 \\
, 105 \\
-, 100 \\
, 941 \\
, 338\end{array}$ \\
\hline
\end{tabular}

a. Test distribution is Normal.

b. Calculated from data.

Table 3 shows the significance of Kolmogorov-Smirnov Z is 0,941 (significance $=0,338$ is higher than $0,05)$, so it can be concluded that $\mathrm{H}_{0}$ accepted and $\mathrm{H}_{1}$ is refused it means that the data between students' writing skill are from the population that is the distribution of normality.

\section{Homogeneity Test}

Homogeneity test towards the research data, the calculation is used SPSS 20.0. A homogeneity test is done to test the hypothesis as follows.

H0: the group of data with the variance that is homogeny (homogeny).

H1: the group of data with the variance that is not homogeny (not homogeny).

Criteria of a hypothesis test are as follows:

Accepted $\mathrm{H}_{0}$ (refused $\left.\mathrm{H}_{1}\right)$ if the significance score (Levene's test) $<0.05$ or Refused $\mathrm{H}_{0}\left(\right.$ Accepted $\left.\mathrm{H}_{1}\right)$ if the significance score (Levene's test) $<0.05$. Here is the result of homogeneity analysis from the four-group sample showed in Table 4.

Table 4 The Computation of Homogeneity Test for Students' Writing Skill in Recount Text

\begin{tabular}{|c|c|c|c|}
\hline \multicolumn{4}{|c|}{$\begin{array}{c}\text { Levene's Test of Equality of Error Variances } \\
\text { Dependent Variable: Writing skill of Recount Text }\end{array}$} \\
\hline F & df1 & df2 & Sig. \\
\hline 2,014 & 3 & 76 &, 119 \\
\hline $\begin{array}{l}\text { Tests the null hypothesis that the error variance of the } \\
\text { dependent variable is equal across groups. } \\
\text { a. Design: Intercept + A + B + A * B }\end{array}$ \\
\hline
\end{tabular}

Table 4 shows the significance 0,119 (significance Levene's test is higher than 0.05 ), so it can be concluded that $\mathrm{HO}$ is accepted and $\mathrm{H} 1$ is refused. It means that the data between students writing skills are from the population are homogeny.

\section{Hypothesis Test of the Research}

The data collection is obtained from the students' writing skill scores for each group. The data analysis is used to test the hypothesis using analysis of variance two ways ANOVAs. Hypothesis test using analysis variance two ways ANOVAs in this research is done in computerized using SPSS 20.0 the result of the calculation is as follows. 
Tabel 5 ANOVA Test

ANOVA Test
Tests of Between-Subjects Effect

Dependent Variable: Writing skill of Recount Text

\begin{tabular}{|l|r|r|r|r|r|}
\hline Source & $\begin{array}{c}\text { Type III Sum } \\
\text { of Squares }\end{array}$ & df & $\begin{array}{c}\text { Mean } \\
\text { Square }\end{array}$ & \multicolumn{1}{c|}{ F } & Sig. \\
\hline Corrected & $10693,181^{\mathrm{a}}$ & 3 & 3564,394 & 54,323 &, 000 \\
Model & 290207,081 & 1 & 290207,081 & 4422,852 &, 000 \\
Intercept & 5737,672 & 1 & 5737,672 & 87,444 &, 000 \\
A & 3067,552 & 1 & 3067,552 & 46,751 &, 000 \\
B & 51,075 & 1 & 51,075 &, 778 &, 380 \\
A $*$ B & 4986,769 & 76 & 65,615 & & \\
Error & 330936,000 & 80 & & & \\
Total & 15679,950 & 79 & & & \\
Corrected & Total & & & & \\
\hline
\end{tabular}

a. R Squared $=, 682$ (Adjusted R Squared $=, 669$ )

1. Hypothesis 1: There is a significant effect of teaching media towards students writing skills in recount text at State Senior High School in Pandeglang.

Based on the data above, the value Sig 0,000 $<0,05$ and Fo is 87,444. This may imply that the research hypothesis is accepted so that it can be concluded there is a significant effect of teaching media towards students writing skill in recount text at State Senior High School in Pandeglang or the other word, it means that there is a different result between teaching media using pictures and conventional approach to the students' writing skill in recount text.

2. Hypothesis 2: There is a significant effect of learning interest towards students writing skill in recount text at State Senior High School in Pandeglang.

Based on the ANOVA data above, the value Sig $0,000<0,05$ and $F_{0}$ is 46,751 . This may imply that the research hypothesis is accepted so that it can be concluded there is a significant effect of learning interest towards students writing skill in recount text at State Senior High School in Pandeglang or the other word, it means that there is a different result between students who have high interest and students who have low interest to the students' writing skill in recount text.

3. Hypothesis 3: There are significant interactive effects of teaching media and learning interest towards students' writing skills in recount text at State Senior High School in Pandeglang.

Based on the ANOVA table above, the value Sig 0,380 >0,05 and $F_{0}$ is 0,778 . This may imply that the null hypothesis is accepted. The research hypothesis is refused so that it can be concluded there is any significant interactional effect of teaching media and learning interest towards students writing skill in recount text at State Senior High School in Pandeglang; in other words, it means that there are any different result between students who have teaching media and high interest and students' who have low interest to the students' writing skill in recount text.

The Value of Adjusted R Squared is 0,669, meaning that the teaching media and learning interest give the effect $66,9 \%$ to the improvement of student's writing skill in recount text at State Senior High School in Pandeglang.

D. Interpretation of Research Results

Based on the research result, it can be arranged into some interpretation of differences of students writing skill test result from each group based on the implementation of teaching media and learning interest towards the students at tenth grade of State Senior High School, are:

1. There is a significant effect of teaching media towards students writing skills in recount text at State Senior High School in Pandeglang.

Based on the research result, it can be stated that the usage of teaching media pictures and conventional approach give direct effect to the students' writing skill test result. It can see clearly from the mean of the result, the students who were taught by teaching media got 72,52 while the students who were taught by conventional approach got 53,03. 
Teaching media plays a significant role in the success of language teaching and learning by creating a solution for both the teacher and the students to cope with the gap between the teachers' explanation/idea and the learners' understanding. Media means of communication and source of information that can be in various forms. They can be in the forms of video/audio recordings, television, diagrams, printed material, tangible objects, computer programs, and instructors. All of them are categorized as instructional media because they provide a message with an instructional purpose to facilitate communication in the learning process. The students would become not interested in learning if the teaching process monotonous. It made the learning process not ineffective. Based on this statement, the English teacher should think critically to find a creative approach in teaching so that the students will participate during the learning process.

Another creative approach in teaching recount text is teaching media. Teaching media are significant. One of the teaching media that is used is pictures. It can be used to guide the students to get the ideas in recount text writing. Using picture are hoped to help the students learn from others through peer review, teamwork, and group discussion. The use of pictures is proper in teaching writing recounts because the media is easy to get.

2. There is a significant effect of learning interest towards the students' writing skill in recount text at State Senior High School in Pandeglang.

Based on research results, learning interest has a significant effect on improving students' writing skills in recount text. In other words, the students who have a high interest are better than the students who have low interest. It can be seen clearly from the mean of the result; the students taught by teaching media and have high interest got 77,54 while the students who were taught by conventional approach got 53,03. Learning interest creates a change in relatively fixed behavior, and that change is done through activities or deliberate efforts. So, what is meant by interest in learning is the psychological aspect of someone who manifests itself in several symptoms, such as desires, feelings of liking to process behavior changes through various activities which include seeking knowledge and experience, in other words, interest in learning is attention, liking, someone's interest (learners) towards learning which is shown through enthusiasm, participation, and activity in learning.

3. There are no significant interactive effects of teaching media and learning interest towards students' writing skills in recount text at State Senior High School in Pandeglang.

Based on the result, teaching media and learning interest give the interaction effects that are not significant towards students' writing skills at State Senior High School in Pandeglang. There are four skills that students should be mastered in learning English. Writing is a part of four language skills necessary to be mastered by the students. This is more urgent than before because the ability to write well is becoming increasingly important in our global community (Weigle,2002). Moreover, the workplace needs people who master English well, especially on the transactional letter. In addition, based on the 2013 Indonesian Curriculum, the students at Senior High School should identify the texts' social function, generic structure, and linguistic features. They are expected to produce short-spoken and written text (Kementerian Pendidikan dan Kebudayaan, 2016). It means that writing has a vital role in English teaching and learning.

We know that writing is one of English skill. It is also so crucial for English learners. Writing is the skill to share ideas what they think. For students, writing is a primary medium through which to demonstrate what they understand. Students will explore their idea; their understanding through writing, and writing is proof of their understanding. Besides that, writing is knowledge transforming. Knowledge transforming is considerably more cognitive complex than knowledge telling because writers do not merely retrieve information already available to them in memory but derive it from reading and integrate it with that already available to become obtained knowledge.

\section{Conclusions}

The research results and analysis show a significant effect of teaching media on students' writing skills in recount text at State Senior High School in Pandeglang Regency. It is proved by the value Sig 0, $000<0,05$ and $F_{o}=87,444$. Next, there is a significant effect of learning interest towards students' writing skill in recount text at State Senior High School in Pandeglang Regency. It is proved by the value Sig 0, $000<0,05$ and $F_{o}=46,751$. Finally, there are significant interactive effects of teaching media and learning interest towards students' writing skills in recount text at State Senior High School in Pandeglang Regency. It is proved by the value Sig $0,380>0,05$ and $F_{o}=0,778$. 
While a good use of words is indicative of good learning, many students struggle to use the right words in their writing. Students are expected to write sentences with no grammar errors, but grammatical errors are the common errors in students' writing. Cohesion, coherence, and mechanics are also characteristics of effective writing, but many students struggle with these micro-skills. Based on the researcher's experiences, some problems are found in the field when giving writing materials to the students, especially the recount text. There are many errors in vocabulary, grammar, and spelling. Another problem is that the students have low motivation and are not interested in doing the task since the writing activities are not enjoyable. Typically, students are forced to compose sentences and paragraphs without any guidance, making it difficult for them to articulate their thoughts on a piece of paper.

\section{References}

Arsyad, A. (2011). Media Pembelajaran. Jakarta. Rajawali Press.

Arikunto, S. (2006). Prosedur Penelitian: Suatu Pendekatan Praktek. Rineka Cipta, Jakarta.

Arikunto, S. (2009). Dasar-dasar Evaluasi Pendidikan. Bumi Aksara, Jakarta.

Brown H D. (1994). Teaching by Principle: An Interactive Approach to Language Pedagogy. New York. Pearson Education, Inc.

Fauziati, E. (2010). Teaching English As A Foreign Language. Surakarta. Era Pustaka Utama.

Harjanto. (2010). Perencanaan Pengajaran.Jakarta. Rineka Cipta.

Hidayat, S. (2013). Teori dan Prinsip Pendidikan. Tangerang: Pustaka Mandiri.

Huda, M. (2013). Model-model Pengajaran dan Pembelajaran. Yogyakarta. Pustaka Pelajar.

Munjin, A. N. \& Kholidah, L. (2009). Metode Dan Teknik Pembelajaran.Bandung: PT Refika Aditama.

Nasution.S.(2011). Metode Research.Jakarta. PT Bumi Aksara.

Pribadi, A. B. (2011). Model Desain Sistem Pembelajaran:Langkah Penting Merancang Kegiatan

Pembelajaran Yang Efektif dan Berkualitas. Jakarta. Dian Rakyat.

Rubiyanto, R. (2011). Metode Penelitian Pendidikan.Surakarta: UMS Press.

Rumini, S. (2011). Kreativitas dan Keterbakatan. Jakarta: PT. Gramedia Pustaka Utama

Sudjana, N. (2010). Penilaian Hasil Proses Belajar Mengajar. Remaja Rosdakarya,Bandung.

Sugiyono. (2012). Statistik Untuk Penelitian. Bandung:Alfabeta

Sugiyono. (2016). Metode Penelitian (Kuantitatif,Kualitatif dan R\&D). Bandung:Alfabeta.

Swadarma, D. (2013). Penerapan Mind Mapping dalam Kurikulum Pembelajaran. Jakarta: PT Elex Media Komputindo.

Taniredja, T. (2011). Model-Model Pembelajaran Inovatif. Bandung. Alfabeta. 